Gut, 1963, 4, 394

\title{
Infection of ascitic fluid in patients with hepatic cirrhosis
}

\author{
D. N. S. KERR, D. T. PEARSON, AND A. E. READ \\ From the Department of Medicine, the University of Durham, Royal Victoria \\ Infirmary, Newcastle-upon-Tyne, and the Department of Medicine, the \\ University of Bristol, and Bristol Royal Infirmary
}

EDITORIAL SYNOPSIS Infection of the ascitic fluid is a treatable complication which can easily escape diagnosis. The clinical features are recorded in this paper. The use of a special trocar and cannula may reduce the risk of infection after paracentesis.

Under normal conditions portal venous blood is sterile (Coblentz, Kelly, Fitzpatrick, and Bierman, 1954; Taylor, 1956) but there is good evidence that bacteria from an infected bowel can migrate into the portal blood stream (Schatten, Desprez, and Holden, 1955; Boden, Rankin, Goulston, and Morrow, 1959; Brooke and Slaney, 1958). These organisms are usually trapped in the liver, which plays a prominent role in the removal of bacteria from the blood (Beeson, Brannon, and Warren, 1945).

Patients with hepatic cirrhosis have an increased and abnormal bowel flora (Martini, Phear, Reubner, and Sherlock, 1957). If these bacteria enter the portal blood they are likely to escape the 'bacterial filter' in the liver since a high proportion of the portalflow in cirrhotics may bypass the liver sinusoids (McIndoe, 1928; Iber, Kerr, Dölle, and Sherlock, 1960; Shaldon, Chiandussi, Guevara, Caesar, and Sherlock, 1961). Having once entered the systemic circulation, they are more than usually prone to survive since cirrhotics have a reduced resistance to infection; for instance, they are subject to septicaemia with organisms of low virulence such as Vibrio foetus and chromobacteria (Coste, Delbarre, Massias, and Elissalde, 1959; Last, 1961). It would therefore be reasonable to expect a high incidence of septicaemia due to bowel organisms in patients with cirrhosis. Since ascitic fluid is an excellent bacterial culture medium, a high incidence of ascitic infection, originating via the blood stream or more directly during paracentesis, would also be anticipated.

TABLE I

SUMMARY OF CASES STUDIED

\begin{tabular}{cll} 
Case No. & Sex & Age \\
\hline 1 & & \\
\hline 2 & M & 39 \\
3 & M & 50 \\
4 & F & 54 \\
5 a & M & 69 \\
$5 b$ & M & 70 \\
6 & F & 46 \\
7 & F & 76 \\
8 a & M & 44 \\
$8 b$ & M & 44 \\
9 & M & 26
\end{tabular}

Presenting Symptoms
Abdominal distension
Abdominal distension, abdominal pain, fever
Abdominal distension, hepatic precoma
Abdominal distension, hepatic precoma
Abdominal distension, abdominal pain, hepatic
precoma
Recurrence of ascites, abdominal pain, coma
Fever, diarrhoea, increasing jaundice
Hepatic precoma, abdominal pain, jaundice
Nil
Flapping tremor, recurrence of ascites
Abdominal distension, backache, hepatic precoma

\begin{tabular}{r}
$\begin{array}{c}\text { Interval } \\
\text { Parace } \\
\text { (days) }\end{array}$ \\
\hline \\
\hline \\
2 \\
2 \\
2 \\
2
\end{tabular}


Nevertheless, reports of coliform septicaemia and peritonitis in cirrhotics are sparse. A few case reports have appeared in the French and American literature (Lemierre, Augier, and MahoudeauCampoyer, 1932; Brule, Hillermand, and Goutner, 1939; Whipple and Harris, 1950; Martin, Spittel, Morlock, and Baggenstoss, 1956; Lemierre and Delbriel, 1956) but the condition attracted little attention until 1958. In that year Caroli and Platteborse described 20 patients with cirrhosis in whom Gram-negative organisms were cultured from blood, ascitic fluid, or both. The authors suggested from their own experience and previous case reports that these complications in cirrhotics produced an atypical clinical picture which was often misdiagnosed. They pointed out that infection of ascitic fluid did not always give rise to the local symptoms of peritonitis and that fever was inconstant. Many of the features which they attributed to coliform septicaemia-diarrhoea, vomiting, hiccough, abdominal pain, increasing jaundice, coma - could easily be mistaken for those of liver failure.

The contention of Caroli and Platteborse that coliform septicaemia and peritonitis are more common than is generally realized, but are frequently misdiagnosed, is borne out by our own experience. We record here 11 episodes of peritoneal infection in nine subjects from a total of 150 patients with cirrhosis seen over four years. All nine had severe portal cirrhosis confirmed by liver biopsy or necropsy. None of these patients had received corticosteroid drugs. The main clinical and laboratory findings are summarized in Table $I$ and are discussed below.

\section{CLINICAL FEATURES}

The presenting symptoms and findings on examination were sufficiently distinct from the classical picture of peritonitis that the correct diagnosis was not made by the first doctor to see the patient on 10 of the 11 occasions. Fever was absent throughout the course of the illness in one patient and only four had high fever (over $101^{\circ} \mathrm{F}$.) at the time when the first positive culture was obtained from blood or ascitic fluid. In two there was low grade fever throughout their hospital stay which was unaffected by control of the infection.

Some degree of abdominal pain or discomfort was present in all our patients but in five it was associated with rapid accumulation of ascites, was described as a distension pain, and was relieved by removal of ascitic fluid. One patient had previously complained of abdominal pain on several occasions when developing hepatic precoma (a fairly common sequence of events in our experience) and the symptom was therefore misinterpreted when she contracted peritonitis. The typical local features of peritonitis-extreme tenderness, guarding, and rebound tenderness-were present in only four of the 11 episodes.

In all the patients portal systemic encephalopathy appeared or increased at the time of the infection.

\begin{tabular}{|c|c|c|c|c|}
\hline $\begin{array}{l}\text { Microscopic Appearance of } \\
\text { Ascitic Fluid }\end{array}$ & $\begin{array}{l}\text { Appropriate } \\
\text { Antibiotic } \\
\text { Therapy Given } \\
\text { for }>24 \text { Hours }\end{array}$ & $\begin{array}{l}\text { Sterilization } \\
\text { of Ascitic } \\
\text { Fluid Achieved }\end{array}$ & Subsequent Course & $\begin{array}{l}\text { Necropsy Findings Other } \\
\text { than Portal Cirrhosis and its } \\
\text { Usual Sequelae }\end{array}$ \\
\hline- & $\begin{array}{l}\text { Yes } \\
\text { Yes }\end{array}$ & $\begin{array}{l}\text { Yes } \\
?\end{array}$ & $\begin{array}{l}\text { Died in hepatic coma after } 1 \text { week } \\
\text { Died in hepatic coma after } 2 \text { days }\end{array}$ & $\begin{array}{l}\text { Stone in common bile duct, } \\
\text { fibrinous peritonitis }\end{array}$ \\
\hline Polymorphs ++ , organisms + & Yes & Yes & Died in renal failure after 6 weeks & - \\
\hline Polymorphs + , organisms + & Yes & Yes & $\begin{array}{l}\text { Required no further paracentesis for } 18 \\
\text { months. Still alive after } 30 \text { months }\end{array}$ & - \\
\hline Polymorphs + & Yes & Yes & Recovered & 一 \\
\hline Purulent & No & No & Died in coma & $\begin{array}{l}\text { Peritonitis, empyema, } \\
\text { purulent meningitis }\end{array}$ \\
\hline Purulent & No & No & Died in coma & Peritonitis \\
\hline $\begin{array}{l}\text { Mononuclear cells }+ \text {, red blood } \\
\text { cells }+ \text {, organisms }+ \\
-\end{array}$ & $\begin{array}{l}\text { Yes } \\
\text { Yes }\end{array}$ & $\begin{array}{l}\text { Yes } \\
\text { Yes }\end{array}$ & $\begin{array}{l}\text { Died of haemorrhage from oesophageal } \\
\text { varices after } 1 \text { week } \\
\text { Recovered }\end{array}$ & $\begin{array}{l}\text { Portal thrombosis, infarction } \\
\text { of } 1 \text { foot of jejunum } \\
-\end{array}$ \\
\hline $\begin{array}{l}\text { Lymphocytes } 70 / \text { c.mm., poly- } \\
\text { morphs } 30 / \text { c.mm. } \\
\text { Polymorphs } 1,900 / \text { c.mm., } \\
\text { lymphocytes } 1,500 / \text { c.mm. }\end{array}$ & $\begin{array}{l}\text { No } \\
\text { Yes }\end{array}$ & $\begin{array}{l}\text { Yes } \\
\text { Yes }\end{array}$ & $\begin{array}{l}\text { Recovered from episode of coma, died } \\
2 \text { months later of haemorrhage from varices } \\
\text { Died } 3 \text { months later of haemorrhage from } \\
\text { varices }\end{array}$ & $\begin{array}{l}- \\
\text { Healing tuberculous } \\
\text { peritonitis }\end{array}$ \\
\hline
\end{tabular}

TABLE I-continued

SUMMARY OF CASES STUDIED 
Four progressed rapidly to hepatic coma and died without regaining consciousness. The frequency of this complication is not surprising; all the patients concerned had severe cirrhosis and had evidence of a considerable porto-systemic venous shunt via oesophageal varices, umbilical veins, etc. Six had developed some manifestation of portal systemic encephalopathy following a previous precipitant such as gastrointestinal haemorrhage or electrolyte disturbance. Hepatic coma or precoma has been a common mode of presentation in previously described cases. Another common manifestation of peritoneal infection was the unusually rapid reaccumulation of ascites following paracentesis which occurred in five patients. The combination of rapidly accumulating ascites and hepatic coma was, not unnaturally, attributed to liver failure on several occasions before a new complication was suspected.

Seven of the nine patients had very obvious finger clubbing, possibly a higher incidence than in unselected cirrhotics, but of no diagnostic help in the individual case. One patient developed finger clubbing for the first time during his infection.

\section{LABORATORY FINDINGS}

The white cell count was consistently below 10,000 per c.mm. in four of the patients, possibly a reflection of hypersplenism, since all had considerable splenic enlargement. The E.S.R. was usually raised but was not helpful in the presence of cirrhosis.

Hypokalaemia was common in these patients before or at the onset of the infection (as it is in any group of severe cirrhotics). All the patients who reaccumulated ascites rapidly showed in some measure the biochemical changes-falling plasma sodium, rising blood urea, and rising plasma potassium-which commonly occur in terminal liver failure (Hecker and Sherlock, 1956).

The concentration of protein in ascitic fluid varied widely in the early stages of the infection and was of no diagnostic value. In three of the five patients in whom this estimation was performed before and after the onset of infection there was a considerably higher concentration on the second occasion.

Wet film examination of the ascitic fluid was carried out as soon as the diagnosis was suspected in six patients and in four there was an obvious excess of polymorphs; bacteria were visible in four specimens. This was a useful confirmation of clinical diagnosis and led to the institution of therapy before the results of culture were available in two patients who survived the infection. The value of this investigation is limited by the lack of a "normal range' of white cell counts on uninfected ascitic fluid. Only two patients had frankly purulent ascites; they had a more acute and rapidly fatal illness than the other patients.

Pathogenic bacteria were cultured from the ascitic fluid in all the patients, this being the criterion of diagnosis. Specimens were plated out on solid media shortly after withdrawal to distinguish infection from chance contamination. Coliforms were obtained from seven patients, Proteus vulgaris, Pseudomonas pyocyanea, Staphylococcus albus, Canidida albicans, and Mycobacterium tuberculosis from one each, three patients having an infection with more than one organism. Culture of blood taken at the same time as the ascitic fluid yielded the same organism in one patient and was sterile in two others. Numerous blood cultures near the time of the ascitic infection were negative in two other patients. Four patients had positive urine cultures at or near the time of the peritoneal infection, but in no case were identical organisms obtained from the two sites. Since in our experience urinary infection is very common in cirrhotics, its occurrence was probably coincidental.

\section{TREATMENT}

Since the equilibration of fairly large molecules such as antibiotics between blood and ascitic fluid takes several hours, it is logical to start treatment by giving both intravenous and intraperitoneal antibacterial drugs. This combined therapy was used in seven patients and sterilization of the ascitic fluid was achieved in six. The subsequent short survival of some of these patients was the result of other complications of their severe liver disease, particularly gastrointestinal haemorrhage.

The yeast infection in case 7 was treated by intraperitoneal administration of Nystatin. This was a desperate measure which did, however, control the infection. Nystatin is almost insoluble in water and cannot be given intravenously or intramuscularly but it has been used previously in body cavities (Sochocky, 1959). Amphotericin B would probably be the drug of choice now. The tuberculous peritonitis in case 9 was resolving satisfactorily on standard antituberculous drugs at the time of his death from haemorrhage.

The infection in case 8 was a transient, selflimiting phenomenon. The fluid became sterile before treatment was instituted on the second occasion.

Seven of the nine pyogenic organisms isolated were sensitive to chloramphenicol; this was also the best antibiotic as judged by sensitivity tests in the experience of Caroli and Platteborse (1958). It is 
therefore the logical choice for emergency treatment. Since long and repeated courses of antibiotics were sometimes required to eliminate the infection, other antibiotics without the risk of marrow aplasia were often substituted when the results of sensitivity tests were available.

\section{SOURCE OF INFECTION}

In two patients necropsy revealed local lesions, an obstructed bile duct and a length of infarcted jejunum which may have been the source of infection. In one patient there was no history of paracentesis and in two others there was a symptomfree interval of at least three weeks between the last paracentesis and the first symptoms attributed to peritonitis. Presumably the infection in these three patients reached the ascitic fluid via the blood stream.

In the remaining five patients paracentesis had been performed within the 10 days before the infection was recognized. This is also true of many of the previously reported patients. There are several possible explanations. Paracentesis might stimulate the passage of bacteria into the portal blood stream, alter the proportion of portal blood bypassing the liver, or reduce the general resistance of the patient to infection. Caroli and Platteborse (1958) favoured some such indirect effect of paracentesis as an explanation. They noted the onset of septicaemia very soon after the start of some paracenteses, before bacteria could be isolated from the ascitic fluid.

However, we have observed the opposite situation, bacteria growing in the ascitic fluid in spite of repeatedly negative blood cultures. Admittedly, negative blood cultures cannot exclude the possibility of intermittent invasion of the blood stream, but we think it is likely that paracentesis sometimes causes direct infection of the ascitic fluid. Since the common infectants are organisms that normally inhabit the bowel, trauma to bowel is presumably a more common hazard than spread of infection from the skin puncture.

\section{TECHNIQUE OF PARACENTESIS}

On the assumption that infection was sometimes due to bowel trauma we enquired into the technique of paracentesis used on these patients and several points emerged. The instruments employed were sharp-pointed; the cannulae were inadequately fixed to the skin so that 'piston movement' was possible if the patient moved in bed; the procedure was often prolonged (in one case for over 24 hours) usually in the belief that rapid decompression of the

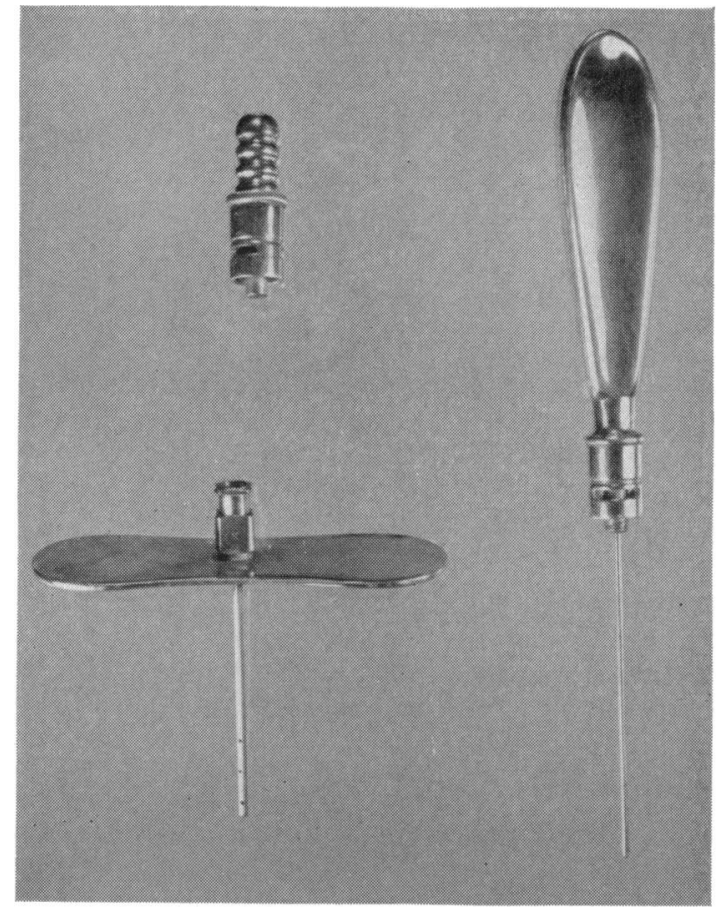

FIG. 1. Trochar and cannula for paracentesis abdominis.

abdomen was dangerous, but sometimes because of intermittent blockage of the cannula or kinking of a narrow drainage tube. Some of the cannulae were unnecessarily wide and liable to leave a drainage track after withdrawal. The procedure had always been carried out in bed in a ward.

These criticisms probably apply to the majority of paracenteses performed in any part of the world. Most of the objections can easily be overcome by use of a properly designed trochar and cannula with a blunt end and a fairly narrow bore $(1 \cdot 5-2 \mathrm{~mm}$. outside diameter), a wide flange for fixation to the skin, and side holes near the tip of the cannula. A Luer-lock or similar attachment permitting quick connexion of a wide-bore drainage tube when the trochar is withdrawn is also an advantage. An instrument of this type is illustrated in Figure 1; it has been in use for four years in various hospitals with satisfactory results; a small nick with a scalpel blade is required to negotiate the skin but it can be pushed through muscle and peritoneum without difficulty in a patient with ascites. Five litres of ascitic fluid can be withdrawn through a cannula of the specified width in two to four hours and it is only necessary to tilt the patient once toward the end of the procedure. We do not believe that paracentesis of this rapidity is more likely to cause shock than slow paracentesis. 


\section{ADDENDUM}

Since this report was compiled we have observed one further patient with spontaneous infection of ascites. A.J., a woman of 40 , with Mediterranean anaemia trait, haemosiderosis, and portal hypertension, was admitted to hospital on account of increasing ascites. During diuretic therapy she at first improved and then deteriorated rapidly with enlargement of the abdomen, distension, pain (relieved by paracentesis), fever (to $101.0^{\circ} \mathrm{F}$.), and vomiting. There was abdominal tenderness but no rebound. The white count was $15,500 / \mathrm{c} . \mathrm{mm}$. in blood and 7,000 in ascitic fluid (mainly polymorphs). Blood culture was negative. Coliforms were grown from ascitic fluid and were sensitive to streptomycin, chloramphenicol, tetracycline, and sulphur amides. She responded to a course of chloramphenicol. No instruments had been inserted into the peritoneal cavity within the three months before the onset of infection.

We are grateful to the various physicians under whose charge these patients were admitted for access to their records. The illustrated trochar and cannula were made for us by Willen Brothers, 44 New Cavendish Street, London, W.1.

\section{REFERENCES}

Beeson, P. B., Brannon, E. S., and Warren, J. V. (1945). Observations on the sites of removal of bacteria from the blood in patients with bacterial endocarditis. J. exp. Med., 81, 9-23.

Boden, R. W., Rankin, J. G., Goulston, S. J. M., and Morrow, Sir W. (1959). The liver in ulcerative colitis: the significance of raised serum-alkaline-phosphatase levels. Lancet, 2, 245-248.
Brooke, B. N., and Slaney, G. (1958). Portal bacteraemia in ulcerative colitis. Ibid., 1, 1206-1207.

Brule, M., Hillemand, P., and Goutner, B. (1939). Septicémie à coli-bacille et péritonite terminale chez une cirrhotique. Bull. Soc. méd. Hôp. Paris, 55, 1167-1169.

Caroli, J., and Platteborse, R. (1958). Septicemie porto-cave: cirrhoses du foie at septicémie à colibacille. Sem. Hóp. Paris., 34, 472-487/SP.

Coblentz, A., Kelly, K. H., Fitzpatrick, L., and Bierman, H. R. (1954). Microbiologic studies of the portal and hepatic venous blood in man. Amer. J. med. Sci., 228, 298-300.

Coste, F., Delbarre, F., Massias, P., and Elissalde, B. (1959). Septicémie à vibrio foetus au cours d'une cirrhose alcoolique avec hémochromatose. Bull. Soc. méd. Hôp. Paris, 75, 69-71.

Hecker, R., and Sherlock, S. (1956). Electrolyte and circulatory changes in terminal liver failure. Lancet, 2, 1121-1125.

Iber, F. L., Kerr, D. N. S., Dölle, W., and Sherlock, S. (1960), Measurement of blood flow in the collateral vessels of the portal vein. J. clin. Invest., 39, 1201-1207.

Last, P. (1961). Personal communication.

Lemierre, A., Augier, P., and Mahoudeau-Campoyer, D. (1932) Sur quelques cas de colibacillémie. Rev. méd. (Paris), 49, 333349.

- and Delbriel, . (1956). Quoted by J. Caroli and R. Platteborse C.R. Soc. méd. Hôp. Paris, p. 300.

Martin, W. J., Spittel, J. A., Morlock, C. G., and Baggenstoss, A. H. (1956). Severe liver disease complicated by bacteremia due to Gram-negative bacilli. Arch. intern. Med., 98, 8-15.

Martini, G. A., Phear, E. A., Ruebner, B., and Sherlock S. (1957). The bacterial content of the small intestine in normal and cirrhotic subjects: relation to methionine toxicity. Clin. Sci., 16, 35-51.

McIndoe, A. H. (1928). Vascular lesions of portal cirrhosis. Arch. Path., 5, 23-42.

Schatten, W. E., Desprez, J. D., and Holden, W. D. (1955). A bacteriologic study of portal-vein blood in man. Arch. Surg., 71, 404409.

Shaldon, S., Chiandussi, L., Guevara, L., Caesar, J., and Sherlock, S. (1961). The estimation of hepatic blood flow and intrahepatic shunted blood flow by colloidal heat-denatured human serum albumin labeled with I 131. J. clin. Invest., 40, 13461354.

Sochocky, S. (1959). Infection of pneumonectomy space with Aspergillus fumigatus treated by "Nystatin". Dis. Chest., $36,554-556$.

Taylor, F. W. (1956). Blood-culture studies of the portal vein. Arch. Surg., 72, 889-892.

Whipple, R. L. Jr., and Harris, J. F. (1950). B. coli septicemia in Laennec's cirrhosis of the liver. Ann. intern. Med., 33 462-466. 